\title{
The effects of Cassia alata L. aqueous leaf extract on the germination of Corchorus olitorius
}

\author{
Silver Ighosotu ${ }^{1}$ and Nyerhovwo J. Tonukari ${ }^{2 *}$ \\ ${ }^{1}$ Department of Chemical Science, Novena University, Ogume, Delta State, Nigeria. \\ ${ }^{2}$ Department of Biochemistry, Faculty of Science, Delta State University, Abraka, Delta State, Nigeria.
}

Accepted 4 April, 2012

\begin{abstract}
The effect of different concentrations of Cassia alata crude aqueous leaf extract on the germination of Corchorus olitorius was investigated. All concentrations of $C$. alata aqueous leaf extract $(10,30,50,75$ and $100 \% C)$ used in this study caused significant $(P<0.05)$ decrease in the total percentage and germination rate of $C$. olitorius. Similarly, all concentrations of this extract significantly $(P<0.05)$ inhibited radicle elongation in $C$. olitorius. Pre-soaking of $C$. olitorius seeds in $C$. alata crude aqueous leaf extract led to an increase in the lag-phase period preceding germination of the seeds in a concentration-dependent manner. The total percentage and rate of germination decreased as extract concentration increased. All concentrations caused a consistent decrease in absolute rate and percentages of germination compared to the control.
\end{abstract}

Key words: Cassia alata, Corchorus olitorius, aqueous extract, germination.

\section{INTRODUCTION}

Corchorus olitorius of the family, Tiliaceae, is grown throughout the Middle East and in some parts of Africa and India as a pot herb (Biswas, 1996). It was chiefly used in India as a source of the bast fiber "tossa jute" (Asaduzzamana et al., 1995). There are about 40 species of Corchorus fairly widely distributed in the tropics but only Corchorus capusularis and C. olitorius are economically important (Benor et al., 2010). C. olitorius (especially, its short branching form) is commonly grown in Africa and Asia as home garden leaf vegetable crops, chiefly because of its tolerance to many soil conditions. Among many communities in Nigeria, its leaves are valued as cooked vegetables mostly because of the high proportion of mucilage they contain (Denton, 1997). Jute fibres are used for the production of Jute sacks, bags, ropes and threads in industries (Liu and Hu, 2010; Lifang et al., 2010).

Cassia alata is a member of the family, Fabaceae (Leguminosae), one of the most important families of flowering plants (Gilman and Watson, 1993; Edward and

\footnotetext{
*Corresponding author. E-mail: tonukari@gmail.com.
}

Dennis, 1993). It is a shrub with pinnate leaves and yellow flowers. The active ingredients in $C$. alata extracts are two alkaloids: anthraquinones and crysanobin (Crockett et al., 1992). Anthraquinones appear to be widespread among the Cassia genus (Nwachukwu and Osuji, 2008).

The medicinal potentialities of the plant have been documented (Ayensu, 1978). The effects of several medicinal plant extracts on other plants have been investigated at different times (Alan and Putnam, 1988; Donald and Briskin, 2000; Wang et al., 2007). Most of these investigations have been at the cytological level in which higher concentrations of the extracts were toxic to parts of the plants.

The present investigation is aimed at studying the different physiological effects of $C$. alata leaf water extracts on $C$. olitorius with regards to the time of germination per week and percentage of germination and radicle length.

\section{MATERIALS AND METHODS}

Germination test of seeds was done according to the method of Smith (1951). 


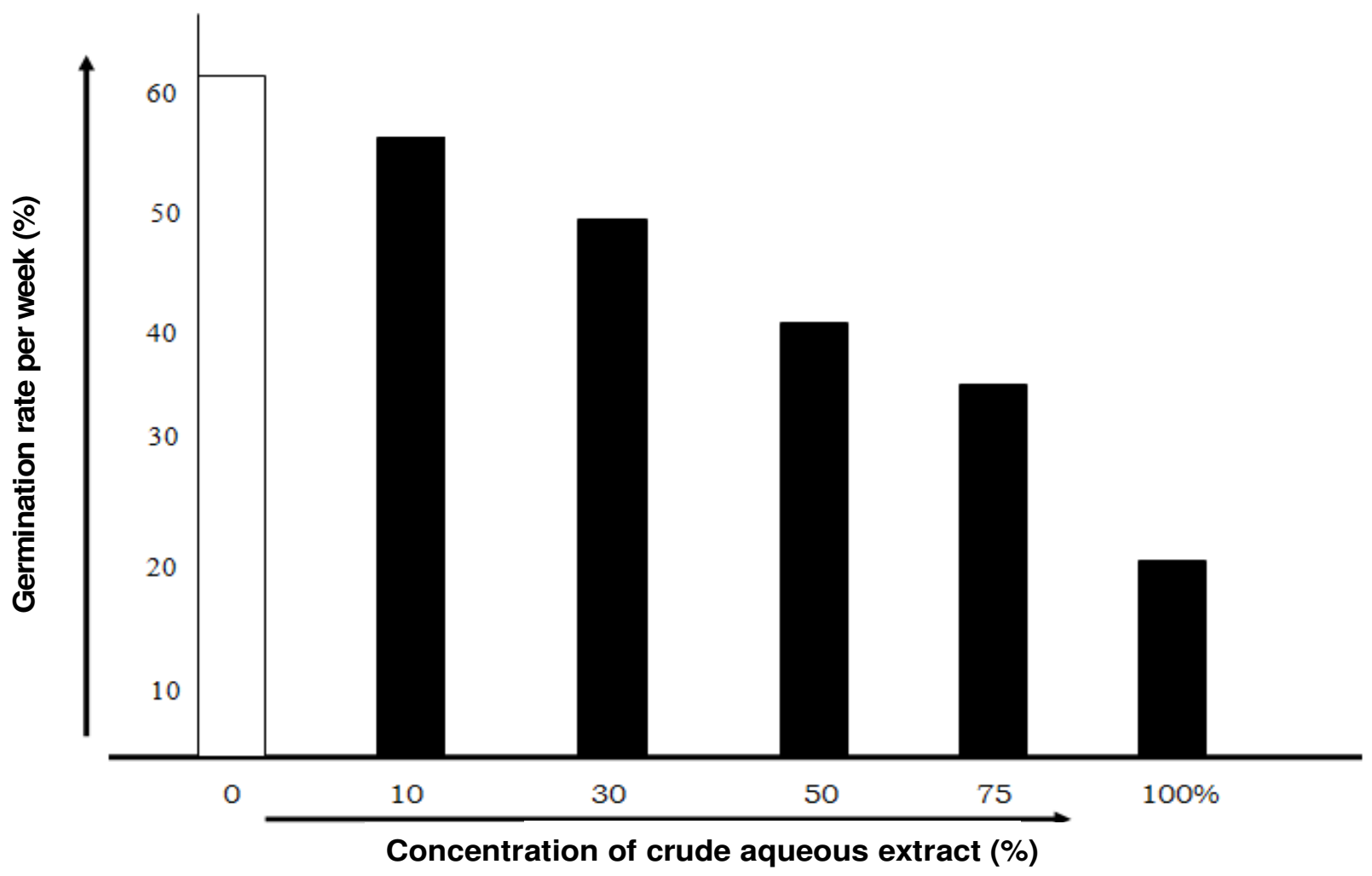

Figure 1. Effect on C. alata crude water extract on germination.

\section{Source of sample}

Seeds of $C$. olitorius used in this experiment were obtained from Mile Three Market, Port-Harcourt, Rivers State, Nigeria. C. alata leaves were obtained from growing stands in the University of PortHarcourt botanical garden. These were authenticated by Dr. Ebigwai Joseph Kayefor of the Botany Department, Delta State University, Abraka with the herbarium number HARL 0001.

\section{Sample preparation}

Three hundred $(300 \mathrm{~g})$ grams of the fresh leaves of $C$. alata was weighed out on a top loading meter balance (model B.163) and blended with a homogenizer in $1 \mathrm{~L}$ of distilled water. The green paste obtained was filtered under suction (model of pump was 850 compressor, s47506FBF). The wine-coloured filtrate was stored in the refrigerator at $-40^{\circ} \mathrm{C}$ until required. This was regarded as $100 \%$ concentration (C). From this stock concentration, lower concentrations of $10,30,50$ and $70 \% \mathrm{C}$ were prepared.

\section{Germination studies}

Petri dishes lined with $9.0 \mathrm{~cm}$ Whatman filter paper, moistened with distilled water were used as germinators. Each treatment comprised of three replicates with fifty seeds each. A control was equally set up for each treatment group. To each Petri dish, $10 \mathrm{ml}$ of the extract $(10,30,50$ and $75 \% \mathrm{C})$ was added and left at room temperature of 25 to $27^{\circ} \mathrm{C}$. Readings were taken at $24 \mathrm{~h}$ intervals and unequivocal emergence of the radicle (that is radicle at least 2 to $5 \mathrm{~mm}$ long) was taken as indication of germination. The lag-phase preceding germination, that is the period after treatment up to the onset of germination, was also recorded.

Seeds pre-soaked in crude aqueous extract for $24 \mathrm{~h}$

Six $8 \times 5 \mathrm{ml}$ beakers, containing 40 seeds of $C$. olitorius each and filled with $10 \mathrm{ml}$ of $0,10,30,50,75$, and $100 \% \mathrm{C}$, respectively, were left to stand for $24 \mathrm{~h}$, and then transferred to moist filter paper in Petri dishes. Readings were taken at $24 \mathrm{~h}$ interval, taking note of the lag-phase preceding germination, germination rate and percentage as well as, emergence of radicle.

\section{RESULTS}

\section{Effect of $C$. alata crude aqueous leaf extract on germination of $C$. olitorius seeds}

Over a period of $48 \mathrm{~h}, \mathrm{C}$. alata crude aqueous leaf extract caused a consistent decrease in the absolute percentage and rate of germination of $C$. olitorius seeds. The seeds in lower concentrations (10 and $30 \%$ C) germinated earlier compared with higher concentrations (50, 75, and $100 \%$ C). At lower concentrations (10 and $30 \%$ C), there was a general decrease in percentage germination as compared to the control. The germination rate and percentage also decreased significantly $(P<0.05)$ with increase in extract concentration (Figure 1). All concentrations of $C$. alata crude aqueous leaf extract used in this study were significantly $(P<0.05)$ inhibitory to radicle 


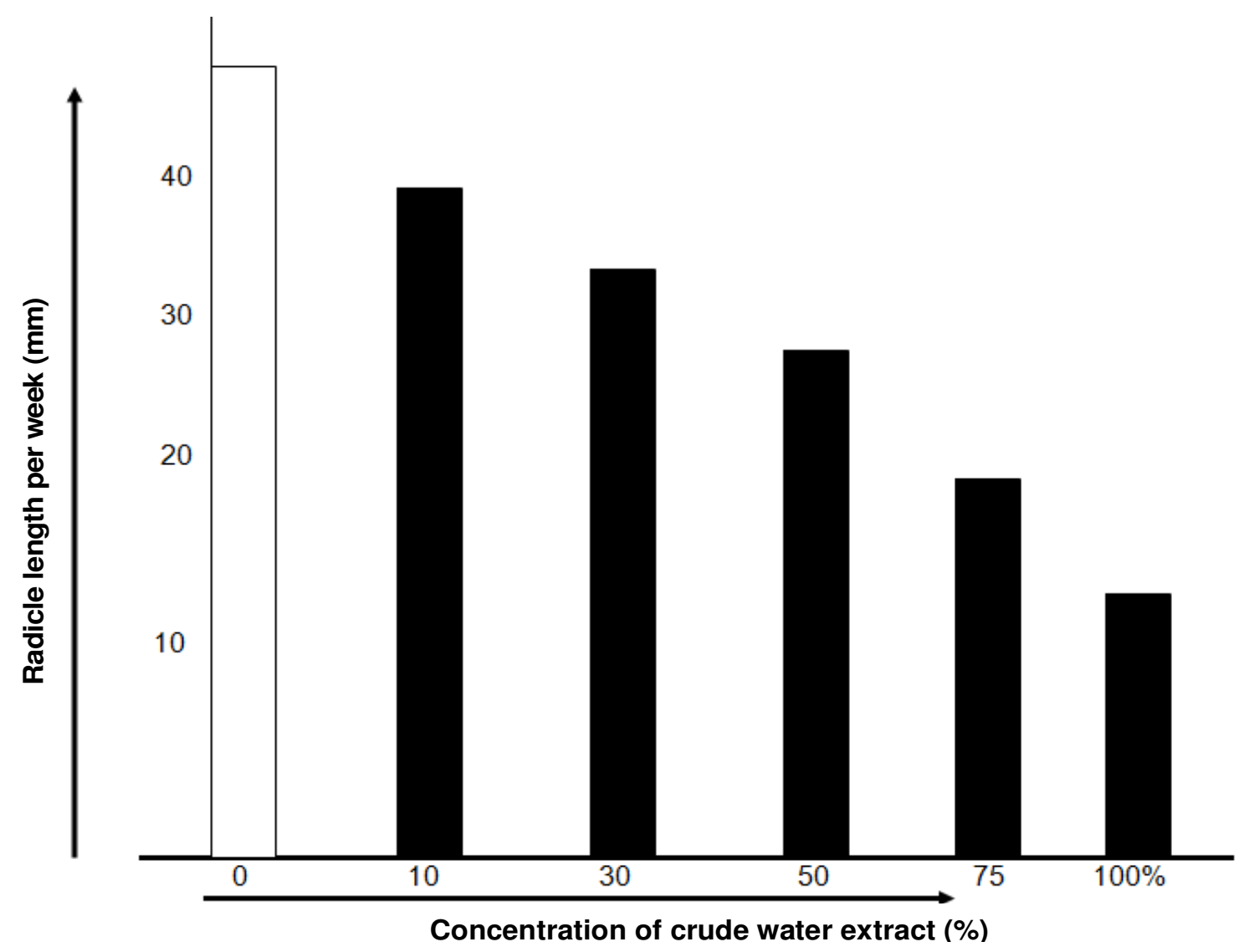

Figure 2. Effect on C. alata crude water extract on radicle length.

elongation (Figure 2).

\section{Pre-soaking of seeds of $C$. olitorius in $C$. alata aqueous extract}

Crude aqueous extract appeared to have longer lagphase period proceeding germination. Certainly, germination percentage and absolute rate of germination decreased with increase in concentration, thus, having a definite trend. The rate of germination of pre-soaked seed was slower and the percentage germination was lower compared with control (Figure 3 ) at $\mathrm{P}<0.05$. These lower concentrations (10 and $30 \% \mathrm{C}$ ) have higher percentage germination when compared with the higher concentrations (75 and $100 \%$ C).

\section{DISCUSSION}

The slower rate of germination and lower absolute percentage germination of $C$. olitorius treated with $C$. alata aqueous leaf extracts is as a result of inhibition of cell division in the embryonic meristems of seeds. Cytomitotic studies on onion leaf root cells (Okoli and Russom, 1986) demonstrated that $C$. alata aqueous leaf extract caused a reduction in the mitotic index. The mechanism of mitotic inhibition by $C$. alata crude aqueous leaf extract, leading to failure or reduced rate of germination of $C$. olitorius which may probably be attributed to the failure of spindle fibre formation, accumulation of prophases over other phases, cmetaphase, stickiness of chromosomes, nuclear lesions and nuclear dissolutions, all of which were observed by some investigators on onion root meristems. Such plants' extracts caused nuclear dissolution which led to the reduced synthesis of DNA, proteins and such cellular components necessary for the growth of the embryonic axes, and as a result, the radicle and/or plumule emergence was delayed or suppressed (Okoli and Russom, 1986). Although, the absolute percentage germination fell below that of the control in all the concentrations used in the present study, a substantial percentage of the seeds were observed to have germinated even in very high concentrations of the extracts. This could be due to the fact that the seeds under such high doses of the extract developed mechanisms that enabled them to tolerate the stress to some extent and thereafter, utilized some nutritious constituents of the extract to their advantage.

At the metabolic level, $C$. alata aqueous leaf extract which can cause DNA polymerization (Okoli and Russom, 1986) invariably inhibited the synthesis of RNA and 


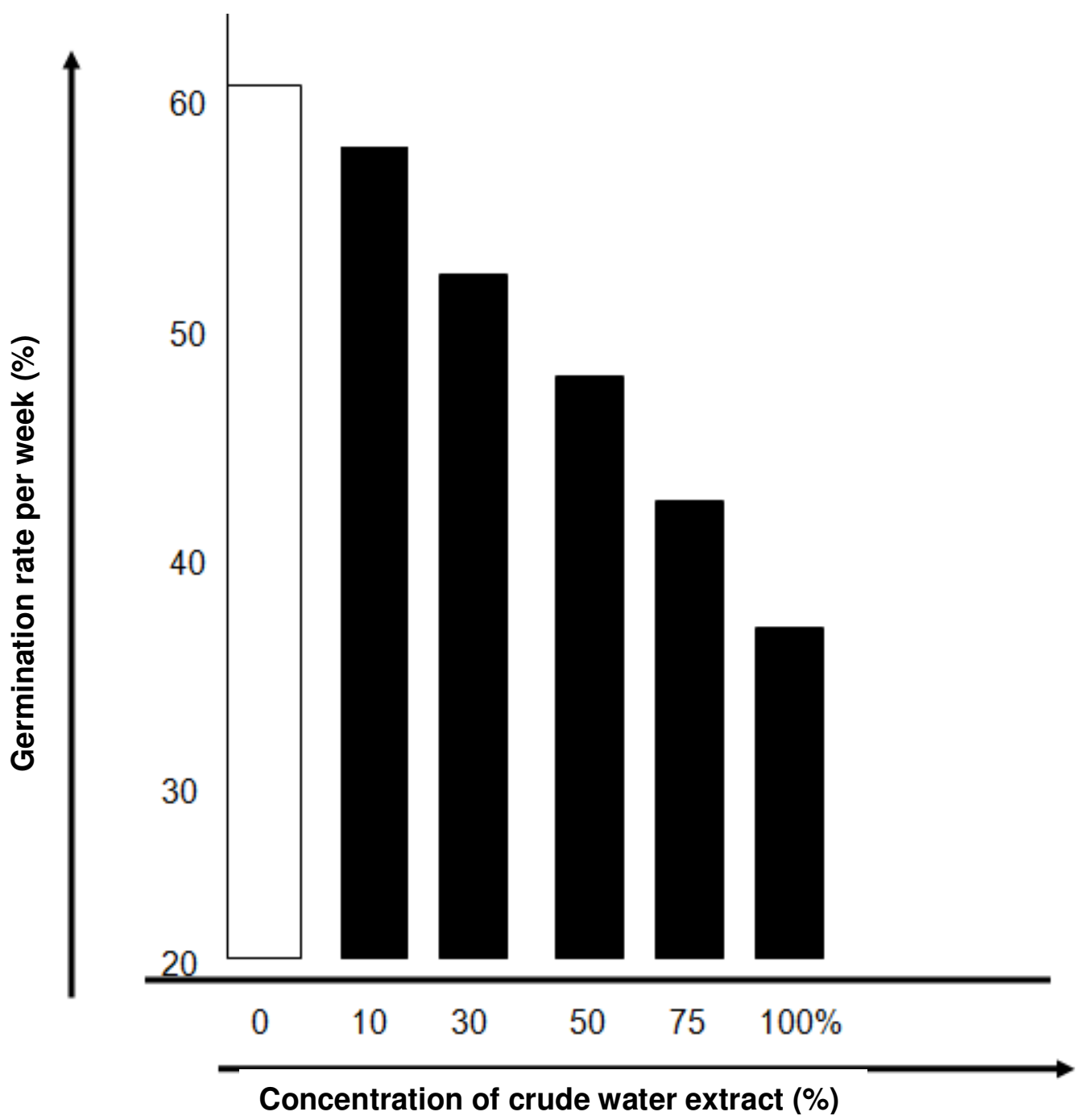

Figure 3. Effects of presoaking seeds of $C$. olitorius on germination percentage and rate.

therefore, de novo synthesis of a-amylase needed for the hydrolysis of starch in the germinating seeds. In germinating seeds, a-amylase synthesis is controlled by the presence of gibberellins (Mayer and Poljakoff, 1975). It thus appears plausible also that the gibberellins synthesis in the seed was disrupted and a-amylase activity was reduced.

Radicle growth in $C$. olitorius was inhibited by all concentrations of the extract used. The inhibition of mitosis and invariably cytokinesis appears to be the main factor inhibiting radicle growth. Inhibition of protein synthesis through DNA depolymerization can also account for reduction in radicle elongation. Although, osmotically active substances play a role in water uptake and cell enlargement is primarily as a result of water uptake and this is dependent on the extent of the availability of hydrophilic colloides as proteins. This is particularly in the embryonic axes of germinating seeds (Małgorzata and Łukasz, 2008). Although, cell division in the radicle may be going on in seeds treated with low concentration, the rate of enlargement of such cells was lower than that of the control. It thus, appears that some of the physiological effects of $C$. alata are a reflection of its cytological effects.

\section{REFERENCES}

Alan R, Putnam (1988). Allelochemicals from Plants as Herbicides. Weed Technol. 2(4):510-518

Asaduzzamana SM, Brighta G, Brooka RM, Hussaina MA (1995). A Novel System of Tossa Jute (Corchorus Olitorius) Husbandry for Seed, Vegetables and Fuelwood. Aust. J. Exp. Agric. 31:205-212

Ayensu ES (1978). Medicinal plants of West Africa Nord. J. Bot. 4:1-38.

Benor S, Blattner FR, Demissew S, Hammer K (2010). Collection and ethnobotanical investigation of Corchorus species in Ethiopia: potential leafy vegetables for dry regions. Genetic Res. Crop Evol. 57(2):293-306.

Biswas DK (1996). Integrated weed control in Jute. In Abstract of papers. Indian Society of Weed Science. p. 68.

Crockett CO, Guede-Guina F, Pugh D, Vangah-Manda M, Robinson TJ, 
Denton L (1997). A review of Corchorus olitorius in Nigeria. Pp.25-30. in Workshop on African indigenous vegetables. Limbe, Cameroon.

Donald P, Briskin (2000). Medicinal Plants and Phytomedicines. Linking Plant Biochemistry and Physiology to Human Health. Plant Physiol.124:507-514.

Edward FG, Dennis GW (1993). Cassia alata: Candlebrush. Fact Sheet ST-125 a series of the Environmental Horticulture Department, Florida Cooperative Extension Service, Institute of Food and Agricultural Sciences, University of Florida.

Gilman EF, Watson DG (1993). Gleditsia triacanthos var. inermis, Thornless Honeylocust. Fact Sheet ST-279, A series of the Environmental Horticulture Department, Florida Cooperative Extension Service, Inst. Food Agric. Sci. Univ. Florida. p. 4.

Lifang L, Qianli W, Zhaopeng X, Jianyong Y, Longdi C (2010). Mechanical modification of degummed jute fibre for high value textile end uses. Ind. Crops Prod. 31(1):43-47.

Liu Y, Hu H (2010). A review on auxetic structures and polymeric materials. Sci. Res. Essays 5(10):1052-1063.
Małgorzata G, Łukasz W (2008). Differential response of antioxidative enzymes in embryonic axes and cotyledons of germinating lupine seeds. Acta Physiol. Plant 30(4):427-432.

Mayer AM, Alexandra P-M (1975).The germination of seeds (2d ed.). Pergamon Press, Oxford, New York. p. 192.

Nwachukwu EO, Osuji J.O.(2008). Evaluation of Plant Extracts for Antifungal Activity against Sclerotium rolfsii Causing Cocoyam Cormel Rot in Storage.Res. J. Agric. Biol. Sci., 4(6):784-787.

Okoli BE, Russom Z (1986). Effects of an aqueous extract of Cassia alata L. on mitosis of Allium cepa roots. Biologia Africana 1(2):31-37. Olubadewo JO, Ochillo RF (1992).Cassia alata and the preclinical search for therapeutic agents for the treatment of opportunistic infections in AIDS patients. Cell Mol Biol. 38(5):505-11.

Smith FE (1951).Tetrazolium salt. Science 29:751-754

Wang S, Hu T, Zhang F, Forrer HR, Cao K (2007). Screening for plant extracts to control potato late blight. Frontiers of Agriculture in China $1(1): 2007$. 